\title{
The Pull and Push Factors of Rural-Urban Teacher Transfer: A Case of Isoka District of Muchinga Province
}

\author{
Ginno M. Sichilima and Ferdinand M. Chipindi \\ University of Zambia
}

\begin{abstract}
This study investigated the factors that push teachers away from rural schools and pull them towards urban and periurban schools. The study used ethnographic research techniques to explore the factors that influence teacher transfers from rural to urban spaces in Isoka district of Northern Zambia. We used purposive sampling to locate and interview teachers and administrators to provide insights into the pull and push factors of teacher transfer. The study uncovered a plethora of reasons for these phenomena. The factors included how the study participants negotiated their relationships with colleagues or superiors. Our research, thus, recommends that the District Education Office in the area needs to be considerate during teacher deployment and placement to suitably place teachers where they can be most productive and settled to avoid transfers.
\end{abstract}

Keywords: Transfer, Deployment, Motivation, Teaching fraternity

\section{INTRODUCTION}

$\mathrm{L}$ ike any other profession, the teaching fraternity requires qualified, dedicated and highly motivated individuals to serve it. These must be ready to expend the best of their pedagogical aptitude towards achieving educational goals (Riley \& Holden, 2012). Wiskow, Albreht and Pieto (2010) assert that to retain this motivated and goal-oriented teaching staff, the educational institutions should pay particular attention to the teachers' needs and what drives their motivation. Thus, motivation has become a critical job management policy that organisations employ to sustain employees' job performance and enhance organisational profitability and survival (Aries, Rizqi, \& Ferry, 2013). Consequently, organisations seeking to maintain an edge in the ever-increasing competitive global market must satisfy their employees' needs to motivate them to remain and thereby mitigate their intention to leave. Preventing employees from leaving is a significant challenge that employers in the education sector encounter. Each employee retains the prerogative of deciding whether to stay or exit the profession. This prerogative is mediated by several factors depending on how well-motivated the employees are (Lankford, Loeb \& Wyckoff, 2002). It is thus, not uncommon to find overwhelming evidence of rural-urban migration, especially in the teaching fraternity (Kaljee et al., 2016)

The migration of employees, mostly from rural to urban areas, has profoundly changed many a city's demographics. The transformation is particularly acute in Sub-Saharan Africa. People vary their location due to factors that either push them away from their original sites or pull them to some new ones. In this article, we argue that migration emanates from a plethora of causes. Still, we can theorise that decision to migrate is often the result of two sets of forces acting on the teacher. The push factors, we theorise, tend to push the teacher away from a location. Simultaneously, the second set of elements will pull the teacher towards another site within the teaching fraternity. The push factors will force people out of such a space; for instance, a shortage of water might lead a teacher to abandon a rural post. Also, low productivity, unemployment, poor economic conditions, and lack of opportunity for advancement may conspire to force an employee out of an area. On the other hand, Pull factors are conditions within another (mostly urban) location that pull or attract or draw people from their homeland to it (Riley, 2011). The push factors may include an opportunity for better employment, high wages, better facilities, and better working conditions constitute the pull factors of migration (Keith, 2009).

\subsection{Statement of the problem}

Intra-system transfer and promotion of personnel, without replacement, may cause understaffing in a system (Okumbe, 2001). The Educational Statistical Bulletin (Ministry of General Education [MoGE], 2018) reveals that there has been a lot of rural-urban drift among teachers in the Republic of Zambia. It has become a trend for teachers in rural posts to seek transfer to urban settings for various reasons. This trend has resulted in inequitable teacher-pupil ratios between urban and rural schools. Urban-rural transfers have been very acute for Muchinga province, in Northern Zambia between 2010 and 2016 (personal communication from the District Education Board Secretary [DEBS] for Isoka district) has been quite significant between the year 2010 and 2016. The high numbers of transfer requests were triggered by diverse motivations including disciplinary cases, desire to join families, health-related factors and wanting to be in an urban set up (Phiri, 2012). Research studies conducted in Muchinga and the neighbouring areas have focussed on many educational issues (Daka, Chipindi and Mukandawire, 2020; Chipindi and Doyle, 2017; Chipindi and Chipindi, 2016; Chipindi, 2017; and Chipindi, 2018). However, these studies 
have seldom emphasised understanding the pull factors that define teachers' motivation to migrate from rural to urban postings and the push factors that could induce a teacher to leave a rural area. Thus, these pull and factors in respect of Muchinga province teachers are unknown. Therefore, this study sought to unravel these factors to deepen our understanding of teacher transfer dynamics in Zambia.

\subsection{Research objectives}

To unravel the pull and push factors that induce rural-urban teacher transfers for Isoka district of Muchinga province of Zambia;

To identify the conditions and circumstances that cause teachers to request to leave their rural posts in Isoka district of Zambia; and

\subsection{Significance of the study}

The study sought to uncover the pull and push factors that induce urban-rural teacher transfer in Isoka district of Muchinga. We hope that this study's results will illuminate the hitherto unknown dynamics of teacher transfers, which might help relevant authorities curb teacher shortages. The study may also provide useful insights into staff retention at the District level and provide continuity in the instructional process. The standard education officers might get helpful information on various teacher issues that can induce or hasten teacher departure from the rural areas if not well handled.

\section{Literature Review}

Teachers may see rural areas as offering fewer opportunities for professional advancement. The cost of pursuing further studies in rural areas is far higher than that of a teacher in the urban area. In most rural areas, transport network and communication networks are so low and discouraging for a teacher to take up studies. This is because a teacher must pay comparatively more than his or her counterpart in the urban area doing the same program. Urban areas are additionally attractive because of ease of access to institutions providing further education and continuing professional development (CPD) opportunities (Hedges, 2000). Institutions offering the required additional training whether by part-time or full time, are usually within walkable distances or distances where the teacher can smoothly go and come back at minimal costs. The opposite is true for the teacher in a rural area. Besides, teachers in rural areas are less likely to engage in other developmental activities, or national consultation or representative organisations. These interactions widen the horizons of thinking for most of the teachers in urban areas. This may well explain why teachers in urban areas make more personal progress than their rural setting counterparts. Ruralbased teachers may also face formidable challenges in obtaining their job-related entitlements such as rural hardship allowance, settling-in allowance and similar perks. The red tape in the government functionalities may also delay the disposal of teachers' work-related queries based in rural outposts. The situation mentioned above is detrimental, and it is not uncommon to find that teachers opt to leave and find spaces where it is less challenging to work. The need for proximity to a spouse is one of the leading causes of transfer requests among Zambian teachers (Phiri \& Mulenga, 2020). Some scholars assert that causes of teacher transfer include: unfavourable working conditions; stress resulting from the poor academic performance of pupils and the resultant pressure from the parents and the Ministry officials; and negligible social amenities in the rural areas (Chabari, 2010; Phiri \& Mulenga, 2020)

The research appears to suggest that teachers may inadvertently find the rural areas more attractive than urban areas. The serene, peaceful, picturesque and relatively safe neighbourhoods associated with rural sites, may provide an additional attraction for the teacher to stay on (Cowan, 2010). Nevertheless, there is overwhelming evidence that what the rural areas have in terms of the environment, is negated by the quality of housing, inadequacy of classroom facilities and the limited access to quality healthcare (Phiri \& Mulenga, 2020). Other commentators similarly assert that professional advancement opportunities, professional isolation, and language barriers may also offer additional attraction (Adedeji \& Olaniyan, 2011).

The research discussed here indicates that teacher transfers, in almost all cases, are nearly always detrimental to the education processes. The transfer of teachers in and out of schools places additional stress on both districts and individual schools. In addition to the high cost of teacher turnover, students are impacted. Turnover negatively impacts students' achievement, and this impact is more pronounced with disadvantaged student populations. This study intended to better understand why teachers migrate based on their lived experiences. This could help schools and districts alike to implement practices that limit teacher migration and the negative impacts that go along with it.

\section{METHODOLOGY}

\subsection{Research Design}

For this research study, we used both qualitative and quantitative dimensions of research. We used the qualitative research design to capture the data beyond the statistics. Creswell (2014) asserts that qualitative research is a systematic approach to exploring naturally occurring phenomena. In this case, the qualitative approach aimed at helping us understand social or human problems. The researcher made interpretations as to the meaning of the collected data. Lichtman (2013) similarly contends that qualitative research focuses primarily on the "why." By this, she means that qualitative research relies on data from observations, interviews, and focus groups and is not focused on measuring or counting (Lichtman, 2013). Many quantitative research studies seek to explore the teaching fraternity dynamics (Thomas, Serenje-Chipindi and Chipindi, 2020; Boe, Bobbitt, \& Cook, 1997; Boe, Cook, \& Sunderland, 
2008; Ingersoll, 2001; Ingersoll, 2003). Most data are primarily premised on surveys and statistics. Thus, it does not draw on the personalised accounts of teachers and administrators who have experienced the transfer phenomenon first-hand. Our study, however, sought to complement the quantitative data by exploring the voices behind the statistics. Thus, a mixture of both qualitative and quantitative approaches was suitable for the current study.

\subsection{Target population}

In common parlance, the target population means the population to which a researcher wants to generalise a study's results (Mugenda \& Mugenda, 2003; and Chipindi 2009). Isoka has 54 schools, of which 9 are secondary schools and 45 primary schools. Per data from the Isoka district Education board office, there have been notable teacher transfer requests in the district, especially among female teachers. Most of the teacher desire to move out of the rural places to the urban areas. The reverse of that is not standard. The DEBS office reports indicate that it has received about $27 \%$ of the total transfer requests from teachers in Isoka district. Thus, our study population comprised of the teachers and headteachers from Isoka district.

\section{3. $\quad$ Sample size and the sampling procedure}

We selected the participants for our study using simple random sampling and purposive sampling. Simple random sampling was ideal for the selection of questionnaire respondents. Purposive sampling was suitable for our research because specific persons were involved in planning, executing, and managing the teacher transfers. These were vital informants and can give more accurate and reliable information on the teacher transfers' status and academic performance. The use of the two sampling methods instead of other sampling designs was informed by the need for respondent specificity and the need to introduce randomness.

\subsection{Research instruments}

Our research utilised primary and secondary data. The former consisted of what we directly obtained from the study participants via the instruments of data collection. We collected secondary data in records from the schools' management and the DEBS at Isoka. Our study intended to understand teachers' lived experiences in the transfer process. Thus, we used interviews as the primary instrument of data collection. The interviews typically lasted about an hour, and we conducted all them in person in a neutral setting selected by the participant. We recorded all the interviews for transcription purposes. We employed a semi-structured approach to encourage discussion and rich dialogue. A semistructured interview, also known as a guided interview, allows the researcher to develop a general set of questions. Additional, follow-up questions can be added based on the situations discussed (Rubin \& Rubin, 2012; Lichtman, 2013). We also used a survey administered to a cluster of randomly selected participants. We used researcher-administered questionnaires (see Appendix II and III) as data collecting instruments.

\subsection{Data Analysis}

The overarching purpose of data analysis was to reorganise and reduce the chunks of data to make empirical and conceptual sense (Chipindi, 2018). We analysed quantitative data using quantitative conventions. We also analysed qualitative data thematically by coding it into emergent themes.

\subsection{Ethical considerations}

We carefully considered ethical issues in conducting our study. Our participants; their confidentiality; and our research's sensitivity to cultural differences, gender and anonymity (Kanuka \& Anderson, 2000) were all given utmost consideration. We disclosed the real purpose of the study. We provided all the relevant facts about the research to decide about participating in the study.

\section{PRESENTATION AND DISCUSSION OF FINDINGS}

\section{Unravelling the Pull and Push factors}

The study's first objective was to describe the teacher transfer's pull and push factors in Isoka District Muchinga Province schools. This objective was realised by asking the school principals and teachers in the area several questions about teacher transfer characteristics in terms of; teachers requesting to leave their schools, teachers requesting to join their schools, the success rates of the transfer applications and the possibilities of obtaining suitable replacements.

\section{The Push Factors}

Not surprisingly, security is also the topmost concern of the teacher respondents. It is the most significant push factor that would compel any teacher in this rural setting to transfer to an urban or peri-urban school. As seen from Table 4.5, lack or compromised job/person/property security is the single most influential factor that can induce a teacher serving in the rural district of Isoka to decide to transfer to an urban school.

Table 4.5: Push Factors

\begin{tabular}{|c|c|c|c|}
\hline \multicolumn{2}{|c|}{ Push factors } & $\begin{array}{c}\text { Freq } \\
\text { uenc } \\
\text { y of } \\
\text { Resp } \\
\text { onse } \\
\text { s }\end{array}$ & $\begin{array}{c}\% \text { of } \\
\text { total } \\
\text { numbe } \\
\text { r of } \\
\text { Respo } \\
\text { nses }\end{array}$ \\
\hline \multicolumn{4}{|c|}{ Socio-Environmental Push Factors } \\
\hline 1 & Poor job, personal and property security & 117 & 97.5 \\
\hline 2 & Lack of accommodares & 51 & 42.5 \\
\hline 3 & Desire to get close to family & 50 & 41.7 \\
\hline 4 & Inadequate teaching facilities & 39 & 32.5 \\
\hline 5 & Students' poor attitude towards learning & 39 & 32.5 \\
\hline 6 & Inconvenience in furthering education & 38 & 31.7 \\
\hline 7 & Poor living conditions & 38 & 31.7 \\
\hline
\end{tabular}




\begin{tabular}{|c|c|c|c|}
\hline 8 & Lack of good schools for children & 36 & 30.0 \\
\hline 9 & $\begin{array}{c}\text { Lack of recreational centres/poor } \\
\text { communication (roads and network) }\end{array}$ & 32 & 26.7 \\
\hline 10 & $\begin{array}{c}\text { Difficulty finding courtship/partner of } \\
\text { standards }\end{array}$ & 15 & 12.5 \\
\hline \multicolumn{4}{|c|}{ Economic Push Factors } \\
\hline 1 & $\begin{array}{c}\text { Lack of other sources of income apart from } \\
\text { salary }\end{array}$ & 71 & 59.2 \\
\hline 2 & Poor remuneration & 53 & 44.2 \\
\hline 3 & $\begin{array}{c}\text { Inability to embark on extra/vacation } \\
\text { classes }\end{array}$ & 50 & 41.7 \\
\hline 4 & Delay in payment of allowances & 29 & 24.2 \\
\hline
\end{tabular}

Source: Field data, 2013/2014

With a frequency of 117 or $97.5 \%$ of the total responses given to the questionnaire, this response indicates that any threat (real or perceived) to the security of a teacher's job, person or property could compel them to vacate their rural teaching post. Therefore, compromised safety in the rural area poses a severe threat to teacher retention in this and other rural areas in Zambia.

Concerning the economic factors, Table 4.5 shows lack of additional income sources (71 or $59.2 \%$ of total responses) as the most crucial push factor that can harm teacher retention in the rural district of Isoka and other rural Zambian environments. Lack of different sources of income as a push factor clarifies that lack of opportunity to engage in other income generation activities to supplement a teacher's salary is a threat to teachers' acceptance of rural posting and their decision to stay in the rural area.

According to the headmasters, many business opportunities exist for teachers in urban areas, mostly as "contract home teachers" who offer extra tuition for students outside school hours and on weekends and school holidays. Home teaching on a contract or itinerant basis, it was learned, is very lucrative and fetches some teachers more money than their monthly salaries. Consequently, some teachers prefer posting to urban schools to find it easy to engage in teaching and other incomegenerating activities to supplement their incomes. Among the many comments made by the headmasters of the schools on this issue were: "home teaching and holiday classes in Mathematics, English language, Biology, Physics and Chemistry is the most attractive business for teachers in towns and cities; even teachers who live in Lusaka and work in rural schools also do it on a part-time basis";

The fact that poor job, personal and property security and lack of opportunity for teachers in this rural community to supplement their salaries could induce a rural teacher to transfer to an urban area is quite threatening. This finding reflects the Herzberg two-factor theory (Yeboah, 2014) which indicates that a lack, absence of or insufficient attention given by the management of any organisation to hygiene or maintenance factors such as employee security can bring about unpleasantness or dissatisfaction. The notion that employees who become dissatisfied with their working conditions could vacate their post reinforces the equity theory.
This theory holds that if workers perceive a level of inequity or unfairness when they compare their work situations to others, they could have the motivation to change the status to generate, at least in their minds, a much better or more accurate sense of fairness. This could lead to employees working less hard or even quitting the job. This scenario calls for the adoption of urgent measures to improve the living and working conditions of teachers who serve in rural areas to be retained in the rural classrooms raise the standard of education in rural areas of Zambia. In the section that follows, we present and analyses the data that we obtained from the interviews.

\section{Teacher Transfers: Unravelling the Pull Factors}

The lived experiences of the teachers who had participated in a transfer transaction were one of the primary foci of this study. We now present a snapshot of these. We highlight relationships that teachers had with their colleagues at the local schools and how these constituted the push and pull factors for teacher transfers. We focus on the relationships the research participants had with their colleagues and the leaders. By leadership, we refer to the headteacher, and the district or provincial officials. Price (2012) asserts that the school and district leadership relationships and the teachers impact teacher satisfaction.

Similarly, high collegiality instances among teachers have been characterised as one of the chief ingredients of effective schools. Almost all participants spoke quite warmly about their school-based colleagues that are members of the teaching staff and the support staff in their schools. Quite a good number of our research participants reported cordial relationships with their colleagues. Their relationship with the school and district leadership was somewhat mixed. While all participants ultimately transferred from an urban to a rural school, those who reported poor relationship with the leadership listed this as the main reason for wanting to be moved.

\section{Relationships with Colleagues}

Many of our participants reported they had excellent relationships with their colleagues. Mwansa and Mulambia said that their relationship with their colleagues was almost at the level of the family. The two even described some of their colleagues as a bit more than the actual family. Mwansa spoke about some of her fellow teachers as 'intake-mates' to emphasise that they were almost of the same age and the same length of service with MoGE. However, she also told us that she was not very close to a significant part of the teaching force. She said she did not even know most of the teachers by name.

Even if I had a very closely-knit family of colleagues, my overall experience was not altogether exciting because there was always the possibility of running into people whom I did not get along with. This can be quite uncomfortable, mostly 
where you felt that the women were not very keen to engage with you. You know how it is with us women; it is quite challenging when you think some hostility, especially from people you consider to be slightly more senior to you in age.

While she and her immediate colleagues were, close and had a great relationship with each other, Mwansa's relationship with the broader teaching staff was far from cordial. Thus, her warm relationship with her intake mates was not enough to keep her from seeking to transfer from Isoka to another school district. The push factor in her story is amply illustrated.

Similarly, Mulambia spoke kindly about his colleagues at the school he chose to transfer from in 2017. He reported the following when we asked him to elaborate:

I've had good colleagues, and they kept me going. There were times during my work life because of disciplinary issues I had faced. At times, I felt that I was just done and should altogether leave the profession. Without some of the friends there, I wouldn't have stayed longer than I did eventually.

Mulambia's recollections reveal that there were times before he finally transferred from the school when he considered leaving. The relationship he had with his colleagues made him reconsider and stay on a little longer. Mulambia's reason for following through with his transfer request was that he had had a hard time getting along with some of the school's leadership. He stated that one senior member of the school leadership was not supportive of his intentions to pursue further studies at the university. He also felt that the school's general management tended to demean junior members of the teaching staff. He felt perturbed by this, and not only did this make him uncomfortable, but he felt like he could not sit around and continue to watch. His frustration with the school leadership was very explicit:

The headteacher and his senior leadership are so openly unwilling to support professional development, probably because they started with primary school certificates. You ask for study leave, and they find a reason to frustrate you. Eventually, I just felt that I could no longer be associated with this unprofessional attitude by the leaders. Thus, I decided to seek a transfer to another province.

One cannot help but recognise that one of the push factors for teacher transfer was their relationship with the leadership.

Other participants reported that colleagues' poor work attitude was why they felt that they would have to request a transfer. Mboyonga, a female teacher who had completed her diploma in 2014 narrated that her relationship with her and the headteacher had deteriorated. The situation had become tenser and tenser over the years. Mboyonga felt that she was doing more work than anyone and that the headteacher was reprimanding her more often than others. For instance, she said to me that "...if you alert the head that someone is not very helpful in shouldering the responsibilities, you might just end up being the problem". This was one reason, she said, she later chose to leave a particular school in Isoka.

\section{Relationship with School Leadership}

Unlike the generally positive relationships with colleagues, participants' relationships with their headteachers or the district leadership were mixed. Some spoke very highly of their headteachers, and others struggled to find positive things to say about their headteachers. Those who struggled to find positive things to say about their headteachers stated that their relationship with the schools' heads was an essential factor in their decision to leave. Those who had positive relationships with their leaders were more likely to stay on. Mbulakulima, Pennell and Mulenga, for instance, reported good experiences with their respective headteachers. Mbulakulima narrated that he had travelled extensively on behalf of the head as he was always willing to delegate duties off the station to him (Mbulakulima). This appeared to build a relationship of mutual trust between him and his head. He stated that he felt the head was particularly interested in building the capacity of the young teachers in the school. "I have attended a lot of Zonal meetings on behalf of my head, and when an opportunity arises for one to travel to Lusaka, you can always count on the head giving you or someone else that chance. You get the sense that he is not greedy to hold-on to opportunities." He said to me during an interview one morning.

Pennell similarly narrated that his relationship with the head was initially not very cordial. He told me that he had been posted to Isoka on his very first appointment in 2014. This meant that several recruits were to accompany him to the new school. The head, he continued, did not receive him very well: "He and I did not get off to a good start at all, by the end of the second year; the relationship had deteriorated very badly". Pennell continued the narration by telling me that he confronted the head at the start of the third year and sought to know if he, the leader, harboured a personal vendetta against him, Pennell. They spoke things through and from then on, they mended their relationships, and from then on, they were on the same page.

Similarly, Kabijimpanga spoke positively about his relationship with his headteacher. He told me that he felt that his headteacher was supportive and would engage in small talk with him on severe school business sidelines. Additionally, he said the school always had openings and that they were "several teachers that would come in and last only a week, two weeks and leave." William mentioned that he thought this "turned off some people" making it difficult to establish a relationship with her. This principal had high amounts of turnover and always had job positions available at her school. Her inability or lack of effort to establish relationships with her teachers potentially contributed to high turnover.

Nachilima's experience with her headteacher was somewhat mixed. She observed that their relationship was interjected with several ups and downs and that there "was a lot of unpredictability" in the headteacher's mood and temperament, making it challenging to work with her leader sometimes. She 
described their relationship as lukewarm but given to certain unpredictable outbursts of warmth: "every day brought its uncertainties, and you could be quite shocked at what the head may throw at you." Nachilima said that she was ultimately thankful that she was grateful that he did not hesitate to recommend her for leadership positions within the zone despite the mood swings. The head put her in charge of the zonal committee, which helped her develop her leadership potential and ultimately helped her secure a better job at the provincial office.

Mwendalubi's situation was somewhat different. He noted that his initial relationship with his headteacher was okay but went hare wire after some time, which caused him to seek a transfer to another school. He recalled an incidence that created friction with his headteacher and strained their relationship to the point where the head "never wanted to speak to me ever again". While Mwendalubi said he initially wanted to stay long in a rural school, where he had established cordial relationships with pupils and their parents, his turbulent relationship with his headteacher and his instincts to fight back, made him realise that it would probably be best to seek a transfer.

Conversely, Chanda, Kabungo, and Makinka struggled with heightened struggles with the district and school leadership. Kabungo and Chanda both reported that they did not get a lot of support from the headteachers and even the district leadership. Kabungo, for instance, stated that the only positive thing she recalled about her head was that he (the head) once sent her for a two-week workshop at Chinsali. The tension between her and the head was evident in those strong words. Similarly, Chanda reported that he would not even speak to his former head if they meet in the future because of what had transpired between them. He narrated that his former head's differences were rooted in tribalism: That school had very strong tribal divisions, and some of us with prominent names did not quite have it so easy. The tribal divide was exacerbated by the headteacher and fostered by like-minded colleagues who, like the head, were tribal, she continued. Chanda recalled that the genesis of the tension was an incidence in which he, and "several colleagues of mine who were Bemba", was unilaterally accused of aiding pupils in cheating in the exam: "From then on, I knew that I had to move or else, I would end up in bigger problems."

Makinka also had problems in the relationship with her headteacher. She described their relationship as "frightening at times". She said he was not looking like someone she could approach anytime for professional guidance. She felt that the head would always minimise her issues, partly because of how he had repeatedly acted in the past by not taking her seriously, for instance.

In the interviews, when we asked about their most negative experience at their former schools which made them decide to transfer, some respondents told me that such negative experience had a lot to do with their headteachers. Mwansa said that the headteacher had double standards in that he did not treat his teachers the same, nor did he have uniform expectations from all of them, being biased towards some of them and not others. She stated the following when I asked her to elaborate: ".. we were expected to do a lot more when other teachers were treated with kids' gloves." Chanda said his worst experience was the accusation that he and his colleagues had helped students with leakages or with answers: "we came to find out that the headteacher knew who had done this but chose to point at us maybe because of our tribe, very appalling". He told me that an investigation carried out by the police showed that Chanda and his colleagues were in no way linked to scandalous behaviour. "My head and I had a huge public altercation in the presence of officials from the DEBS and the Police".

Similarly, Mwango said she felt that the headteacher was a wizard because he seemed to be looking forward to her doing something wrong that warranted disciplinary action. "He was looking for you to commit some crime." She explained that the headteacher was always quick to resort to a written warning and would not hesitate to state the consequences of losing your job, for example. These negative experiences appear to have inspired my respondents to request to be transferred from their schools. Thus, we can count them as among the push factors that highlight the voices behind the statistics.

The lack of trust and the presence of suspicion among these participants and their former headteachers seemed to poison their relationship and pushed them to move or request to move to another school. More than half of the participants told me that their relationships with their former headteachers were negative or mixed which, for some, was their primary reason for requesting to be transferred and for others, was a part of their reason for leaving. Others who had positive relationships with their former headteachers choose to go regardless of their relationship. This speaks to the point that the decisions to make transfer requests were not always based on a single event or experience, resulting from multiple and often complex issues.

\section{Effects of Teacher Transfer on Students' Academic Performance}

Regardless of their motivations, teacher transfers profoundly impacted pupils' academic performance in the affected area. We theorise that transfers had a vast potential to affect student performance negatively. If teachers in rural areas are pushed away from rural areas and pulled to urban areas, student performance in rural areas will likely not be affected negatively. Similarly, if the rural areas' conditions are favourable enough to pull the teachers to stay put, performance is likely to be negatively affected.

The departure of the teacher may result in a decline in pupil morale and performance. The opinions of some headteacher in Isoka corroborated this view. If the departing teacher were in charge of a grade nine or grade 12 class, then the disruption to classroom progress of the pupils would be colossal. "If a 
teacher in charge of the terminal class, one that is preparing for examinations, then examination preparations would be thrown into disarray". These sentiments accord with Mubanga (2009) 's assertion that finding specialist teachers in certain subjects is a difficult task in Zambia. When teachers transfer from the rural areas, it is hard for the DEBS to send a replacement since very few teachers are willing to post to the rural areas. Knowing that the implications of teacher transfer from rural to urban make it very necessary for the Ministry of Education to implement measures such as incentivising rural teaching posts with a "rural hardship allowance equivalent to $20 \%$ of the teachers' salary.

\section{CONCLUSION}

Although our study was limited to Isoka district, the results unravel factors that occur as part of the broader dialogue on teacher transfer. Our research has shown that several factors can take teachers away from the rural district of Isoka in Muchinga and negatively affect educational standards in the area. Student performance raises much concern because regardless of a school's location in the rural or urban setting, all final-year students in Zambia must write the examination.

Teachers' refusal to accept rural teaching posts and their unwillingness to stay in rural areas should be a source of concern to the Republic of Zambia. Zambia's government would have to provide the necessary educational resources and infrastructural development to improve teachers' service conditions in rural Zambia to ensure that job and none-job conditions in the rural areas could pull more teachers to stay, push fewer teachers to migrate to urban areas.

We recommend that Zambia's Government implements the proposed $20 \%$ of basic salary incentive for teachers who accept posting to rural and deprived areas of Zambia to compensate for the lack of additional income sources. This incentive can also boost teacher satisfaction and encourage them to work harder to bridge the rural-urban gap in educational standards and student achievement in Zambia. The Teaching Service Commission, which is the primary employer of teachers in Zambia, should reflect carefully on the factors that would affect teacher transfers in this and other locations. The schools should also provide social amenities for the teaching staff such as good schools for their children, adequate housing, access to health and recreational facilities.

\section{REFERENCES}

[1] Adedeji S.O. \& Olaniyam, O. (2011). Fundamentals of teacher education development 2: Improving the conditions of teachers and teaching in rural schools across African Countries. Addis Ababa: UNESCO.

[2] Aries, S., Rizqi, M., \& Ferry, J. (2013). Analysis of the effect of attitude towards works, organisational commitment, and job satisfaction on employees' job satisfaction. European Journal of Business and Social Sciences, 1 (10) 15-24,

[3] Boe, E. E., Bobbitt, S. A., Cook, L. H., Barkanic, G., \& Maislin, G. (1998). Sources of supply of teachers for eight Coonate areas: National trends and predictors. (Data Analysis Report No. 1998DAR2). Philadelphia: the University of Pennsylvania, Graduate School of Education, Center for Research and Evaluation in Social Policy.
[4] Boe E.E., Cook L.H. \& Sunderland, R.J. (2008). Teacher turnover: examining exit attrition, teaching area transfer, and school migration. Exceptional Children, 75(1), 7-31.

[5] Cowan, T.H. (2010). Teacher perspectives on factors that affect teacher attrition and retention in rural middle schools of North Carolina (Unpublished doctoral dissertation). Western Carolina University, USA.

[6] Chabari, B.E. (2010). Challenges facing effective implementation of free secondary education in public secondary schools in Kangundo district, Kenya (Unpublished masters thesis, Chuka University College, Chuka, Kenya)

[7] Chipindi, F. M. (2009). The quality-quantity trade-off: Implications of expanded enrolments at two of Zambia's public universities (Unpublished master's dissertation). University of Zambia, Lusaka. http://dspace.unza.zm/handle/123456789/348

[8] Chipindi, F.M. (2017). Neoliberal governmentality, responsibilisation and the deepening of academic tribalism in the Zambian academy: A commentary. International Journal of MultiDisciplinary Research. ISBN (online): 3471-7102. https://www.researchgate.net/publication/320979075_Neoliberal_ governmentality_responsibilization_and_deepening_academic_tri balism_in_the_Zambian_academy_a_commentary

[9] Chipindi, F.M. (2018). Negotiating professional identities in a liberalised Sub-Saharan economy: A case of University of Zambia faculty (unpublished $\mathrm{PhD}$ dissertation). University of Minnesota, Minneapolis.

[10] Chipindi, F.M. \& Doyle, H. (2017). Zambia scoping study. In H. Doyle, A.M. Barrett \& A. Reeves (Eds.), Improving the quality of teaching in secondary education: scoping studies for Zambia, Malawi, Tanzania, Côte D'Ivoire and Senegal (pp. 4-32). Bristol: Bristol University. http://dspace.unza.zm/handle/123456789/6744

[11] Chipindi, F.M. \& Chipindi, S.J. (2016). Trade-off issues in teacher education at the university of Zambia: Growing student numbers and the quality of teacher education processes. International Journal of Teaching and Learning in Africa 3(1), 82-86. http://dspace.unza.zm/handle/123456789/6745.

[12] Chipindi, F.M. \& Vavrus, F. (2018). The ontology of mention: Contexts, contests, and constructs of academic identity among the university of Zambia faculty. FIRE: Forum for International Research in Education, 4, (3), 102-116. ISSN: 2326-3873.

[13] Daka, H., Chipindi, F.M. \& Mwale-Mkandawire, M. (2020). The relationship between assessment practices and students' academic performances. A case of undergraduate students at the medical school of the university of Zambia, 2008 - 2016. Zambian Journal of Educational Management, Administration and Leadership, 1, (1), 143-156. ISSN: 2706-7416 (Print). http://dspace.unza.zm/handle/123456789/6742.

[14] Hedges, J. (2002). The Importance of Posting and Interaction with the Education bureaucracy in becoming a teacher in Africa. International Journal of Educational Development 22, 353-366.

[15] Ingersoll R. M. (2001). Teacher turnover and teacher shortages: An organisational analysis. American Educational Research Journal, 38 (3), 499-534.

[16] Ingersoll, R. (2003). Is there really a teacher shortage? A Research Report Co-sponsored by the Consortium for Policy Research in Education and The Center for the Study of Teaching and Policy.

[17] Kaljee, L. Zhang, L. Langhaug, L. Kelvin Munjile, K., Tembo, S., Menon, A. Stanton, B., Li, X. \& Malungo, J. (2016): A randomised control trial for the teachers' diploma programme on psychosocial care, support and protection in Zambian government primary schools. Psychology, Health \& Medicine, 1-13.

[18] Keith, S. G. (2009). Push and pull factors of migration; A case study of brick kiln industry of Punjab state. Asia-Pacific Journal of Social Sciences, 1, 84-85.

[19] Kanuka, H., \& Anderson, T. (2007). Ethical issues in qualitative elearning research. International Journal of Qualitative Methods, 20-39.

[20] Lankford H, Loeb S, Wyckoff J. Teacher Sorting and the Plight of Urban Schools: A Descriptive Analysis. Educational Evaluation and Policy Analysis, 24 (1),37-62. 
[21] Lichtman, M. (2013). Qualitative research in education: A user's guide (3rd ed.). Thousand Oaks, CA: SAGE.

[22] Mubanga, A. (2005). Teachers for rural schools: A challenge for Africa (Report on Ministerial Seminar on Education for Rural People in Africa: Policy Lessons, Options and Priorities, Africa Region World Bank).

[23] Mugenda, O.M. \& Mugenda A.G. (2003). Research methods: quantitative and qualitative approaches. Nairobi: ACTS Press,

[24] Mulinda, T (1990) Evaluating research for Beginners.A practical study. Bonn: Deut stifling for international Entwicklung.

[25] Mukuka A (2005). Teachers for Rural Schools: A challenge for Africa. African Region World Bank Working Document. Addis Ababa: World Bank

[26] Mwalala, D. (2008). The influence of headteacher leadership styles on KCE Performance in public secondary schools in Taitadistruict. (Unpublished M.Ed dissertation), University of Nairobi, Kenya).

[27] Nukunya, G. K. (2003). Tradition and change in Ghana: An introduction to sociology. Accra: Ghana Universities Press.

[28] Okumbe J. A. (2001), Educational management: Theory and practice. Nairobi: Nairobi University Press.
[29] Price, CJ (2012). A review and synthesis of the first 20years of PET and fMRI studies of heard speech, spoken language and reading. NeuroImage, 62 (2), 816-847.

[30] Riley, MA and Holden, J.G. (2012), Dynamics of cognition. WIREs Cognitive Science, 3, 593-606. https://doi.org/10.1002/wcs. 1200

[31] Rubin, H.J. and Rubin, I.S. (2012). Qualitative interviewing: The art of hearing data. 3rd Edition, Thousand Oaks: Sage.

[32] Thomas, M. A.M., Serenje-Chipindi, J \& Chipindi, F.M. (2020), Comparing course syllabi from A to Z: Examining the contexts, content, and concerns for social foundations of education in Australia and Zambia. In A. E. Mazawi \& M. Stack (Eds.). Course Syllabi in Faculties of Education across the World: Bodies of Knowledge and their Discontents (pp 38-50). Sydney: Bloomsbury, ISBN 978-1-3500-9425-3 (hardback) 978-1-35009427-7 (online). http://dspace.unza.zm/handle/123456789/6619.

[33] UNESCO (2006). Teacher Motivation, Compensation and Working Conditions. Paris: UNESCO

[34] Wiskow C, Albreht T, de Pietro C (2010). How to create an attractive and supportive working environment for health professionals. Health Systems and Policy Analysis, 48, 1-26. 